\title{
ANALISIS STRATEGI BELAJAR MANDIRI SISWA KELAS VI DALAM MENGHADAPI UJIAN DI SEKOLAH DASAR
}

\author{
Aji Heru Muslim*, Wakhid Imanulloh
}

Universitas Muhammadiyah Purwokerto, Purwokerto, Jawa Tengah 53182, Indonesia

\begin{abstract}
Abstrak
Penelitian ini bertujuan untuk mengetahui strategi belajar mandiri siswa kelas VI dalam menghadapi ujian di SD Negeri 1 Kedungwuluh Kidul. Penelitian ini menggunakan metode penelitian kombinasi (Mixed Method). Populasi dalam penelitian ini yaitu siswa kelas VI yang berjumlah 28 siswa. Data penelitian diperoleh dari hasil angket dan wawancara pada siswa. Teknik analisis data yang digunakan pada metode kuantitatif menggunakan persentase dan pada metode kualitatif menggunakan teknik analisis data model Miles and Huberman. Hasil penelitian menunjukan bahwa sebagain besar siswa SD Negeri 1 Kedungwuluh Kidul menggunakan strategi bertanya yang masuk dalam kategori strategi belajar elaborasi dengan persentase $60,7 \%$. Kedua yaitu menggarisbawahi yang masuk dalam kategori strategi belajar mengulang dengan persentase $57,1 \%$. Ketiga yaitu mengulang yang masuk dalam kategori mengulang dengan persentase $53,5 \%$.
\end{abstract}

Kata kunci: Strategi Belajar Mandiri; Ujian; Sekolah Dasar

\section{Abstract}

This study aims to determine the self-learning strategies of class VI students in facing examinations at SD Negeri 1 Kedungwuluh Kidul. This study uses a combination research method (Mixed Method). The population in this study were class VI students, amounting to 28 students. The research data was obtained from the results of questionnaires and interviews with students. Data analysis techniques used in quantitative methods use percentages and in qualitative methods using data analysis techniques model Miles and Huberman. The results of the study showed that the majority of SD Negeri 1 Kedungwul Kidul students used questioning strategies included in the category of elaboration learning strategies with a percentage of $60.7 \%$. The second is underlining the categories of repeat learning strategies with a percentage of $57.1 \%$. Third is repeating the repetition category with a percentage of $53.5 \%$.

Keywords: Independent Learning Strategy; Exam; Elementary School

\section{Pendahuluan}

Pendidikan merupakan usaha yang sengaja dirancang oleh pemerintah untuk mencapai tujuan yang ditetapkan, salah satu tujuannya yaitu untuk meningkatkan sumber daya manusia yang berkualitas. Pendidikan merupakan hal yang penting dalam kehidupan setiap manusia yang berarti bahwa setiap manusia berhak mendapatkan perkembangan pendidikan.
Proses pendidikan yang berlangsung tidak terlepas dari kurikulum sekolah yang di berikan oleh pemerintah sebagai acuan guru melaksanakan proses pembelajaran. Kurikulum yang di terapkan di sekolah dasar masih berbeda-beda disetiap sekolah yaitu ada yang menerapkan kurikulum 2013 dan kurikulum tingkat satuan pembelajaran (KTSP). Dalam kurikulum 2013 pembelajaran disajikan dalam bentuk tematik atau terintegrasi dan dalam pembelajarannya menggunakan pendekatan 
saintifik, sedangkan kurikulum KTSP dalam pembelajarannya disajikan dalam bentuk per mata pelajaran atau perdisiplin ilmu tidak terintegrasi. Banyaknya mata pelajaran yang dipelajari siswa di sekolah dengan jumlah jam belajar di sekolah setiap hari hanya 6 jam menyulitkan guru dalam menyampaikan materi pembelajaran secara menyeluruh dan keberhasilan proses pembelajaran bergantung pada hasil belajar siswa yang dapat dilihat dengan ulangan, tes, dan ujian.

Ujian akhir merupakan penentu kelulusan bagi setiap siswa untuk melanjutkan ke jenjang sekolah selanjutnya. Ujian Sekolah Berstandar Nasional (USBN) yang diselenggarakan oleh pemerintah merupakan suatu kegiatan untuk mengukur tercapainya kompetensi siswa yang dilakukan oleh satuan pendidikan di seluruh Indonesia yang mengacu pada standar kelulusan untuk memperoleh ijazah atau prestasi belajar. Peraturan Badan Strandar Nasional Pendidikan Nomor: 0045/BSNP/II/2018 BAB $\mathrm{V}$ tentang pelaksanaan USBN SD/MI/SDTK/SPK menyebutkan beberapa mata pelajaran yang diujikan dalam USBN di sekolah dasar diantaranya yaitu Bahasa Indonesia, Matematika, dan Ilmu Pengetahuan Alam (IPA) dan waktu pelaksanaannya yaitu pada tanggal 3, 4, dan 5 Mei 2018 dan ujian susulan pada tanggal 7, 8, dan 9 Mei 2018, sedangkan untuk Ujian Sekolah (US) sepenuhnya disiapkan oleh satuan pendidikan yang mengacu pada standar kompetensi sesuai dengan kurikulum yang berlaku. Standar kelulusan sesuai dengan yang telah di tetapkan oleh pemerintah dan satuan pendidikan dan target kelulusan yang diinginkan oleh sekolah yaitu $100 \%$ lulus dengan nilai maksimal dan memuaskan.

Bagi sekolah terutama guru, tingkat kelulusan siswa menjadi prioritas utama untuk meningkatkan mutu sekolah dan menyangkut akreditasi sekolah. Dibutuhkan strategi untuk meningkatkan kelulusan siswa diantaranya yaitu dengan memprediksi siswa yang sudah menguasai materi dan siswa yang masih kurang menguasai materi dengan melihat nilai yang diperoleh siswa. dengan demikian, guru dapat berkonsentrasi meningkatkan proses belajar mengajar terutama bagi siswa yang masih kurang menguasai materi. Strategi lain yaitu dengan menambahkan jam pelajaran atau les yang dilaksanakan setelah jam pelajaran selesai untuk meningkatkan penguasaan materi siswa. Tidak hanya sekolah dan guru, siswa juga dituntut untuk mempersiapkan diri dalam menghadapi ujian di sekolah. Dibutuhkan persiapan bagi siswa diantaranya yaitu menjaga kesehatan, membuat catatan, mengerjakan soalsoal dan melakukan belajar setiap hari untuk meningkatkan penguasaan pengetahuan siswa.

Setiap siswa memiliki kemampuan kerja otak yang berbeda, sehingga pengetahuan yang mereka dapat tidak akan pernah sama dengan teman lainnya. Penting bagi mereka belajar sesuai dengan strategi belajar yang dimilikinya. Belajar menurut Purwanto (2014: 85) merupakan suatu perubahan yang terjadi melalui latihan atau pengalaman, dalam arti perubahan-perubahan yang disebabkan oleh pertumbuhan atau kematangan tidak dianggap sebagai hasil belajar. Kegiatan belajar, siswa lakukan setiap waktu sesuai dengan keinginan siswa baik malam hari, siang hari, sore hari, maupun pagi hari serta dilakukan dengan melibatkan dua unsur, yaitu jiwa dan raga. Belajar yang efisien dapat tercapai apabila siswa dapat menggunakan strategi belajar dengan tepat. Strategi belajar sangat diperlukan guna untuk mencapai hasil belajar yang semaksimal mungkin.

Suyono \& Hariyanto (2014: 12) mengatakan bahwa siswa yang telah memahami strategi belajarnya sendiri akan lebih cepat dan mudah dalam belajarnya dan belajar dikatakan berhasil jika seseorang mampu mengulangi kembali materi yang telah dipelajarinya. Strategi belajar sangatlah penting bagi siswa untuk memahami dan menerapkan ilmu pengetahuan serta menentukan keberhasilan saat ujian. Strategi belajar dapat dikembangkan secara optimal apabila telah diketahui strategi belajar yang dimiliki siswa, maka dari itu penting bagi guru untuk mengetahui dan 
menganalisis bagaimana strategi belajar mandir siswa dalam menghadapi persiapan ujian.

Berdasarkan hasil wawancara dengan guru kelas VI di SD Negeri 1 Kedungwuluh Kidul mengatakan bahwa tingkat keseriusan siswa dalam belajar disekolah menjelang ujian masih sama seperti biasanya, belum mengalami peningkatan dalam belajar dan guru belum melihat/mengetahui strategi belajar seperti apa yang siswa gunakan dalam menghadapi ujian, akan tetapi di SD tersebut dalam kurun waktu 5 tahun selalu LULUS 100\% dengan kategori baik di UPK Patikraja. Hal demikian yang mendorong peneliti untuk melakukan penelitian yang berjudul "Analisis Strategi Belajar Mandiri Siswa Kelas VI dalam Menghadapi Ujian di Sekolah Dasar".

\section{Metode Penelitian}

Metode penelitian yang digunakan dalam penelitian ini adalah metode kombinasi (Mixed Methods) atau desain Sequential Explanatory. Penelitian ini bertujuan untuk mengetahui strategi belajar dan bentuk staregi belajar mandiri siswa kelas VI dalam menghadapi ujian di SD Negeri 1 Kedungwuluh Kidul. Populasi dalam penelitian ini adalah seluruh siswa kelas VI di SD Negeri 1 Kedungwuluh Kidul yang berjumlah 28 siswa.

Teknik pengumpulan data yang digunakan dalam penelitian ini yaitu menggunakan angket dan pedoman wawancara. Angket menurut Arifin (2012: 228) adalah pengumpulan data dengan cara memberi serangkaian pertanyaan atau pernyataan tertulis untuk menjaring data terhadap responden untuk dijawab sesuai dengan kondisinya. Angket dikembangkan dari teori-teori strategi belajar yang kemudian dibuat menjadi kisi-kisi soal, dari kisi-kisi soal tersebut dikembangkan lagi menjadi butir-butir soal angket. Dalam penelitian ini metode yang digunakan oleh peneliti adalah metode angket tertutup karena responden tinggal memilih jawaban yang telah disediakan. Angket disini terdiri dari 22 item dengan alternatif jawaban yang digunakan adalah sebagai berikut: a. SL (selalu) dengan skor 4

b. SR (sering) dengan skor 3

c. JR (jarang) dengan skor 2

d. TP (tidak pernah) dengan skor 1

Wawancara menurut Arifin (2012: 233) adalah pengumpulan data yang dilakukan melalui percakapan dan tanya jawab dengan responden untuk mencapai tujuan tertentu. Wawancara dilakukan terhadap siswa dilaksanakan di sekolah setelah selesai pembelajaran. Dalam wawancara peneliti memberikan pertanyaan-pertanyaan kepada masing-masing partisipan terkait dengan bagaimana strategi belajar mandiri siswa dalam menghadapi persiapan ujian.

\section{Hasil dan Pembahasan}

Hasil angket strategi belajar mandiri siswa menghadapi persiapan ujian dapat dilihat pada tabel dibawah ini:

Tabel 1. Hasil angket strategi belajar mandiri menghadapi ujian

\begin{tabular}{|c|c|c|c|c|}
\hline No & Kategori & Pernyataan & $\begin{array}{l}\text { Jumlah } \\
\text { Siswa }\end{array}$ & $\begin{array}{l}\text { Perse } \\
\text { ntase }\end{array}$ \\
\hline $\mathbf{A}$ & \multicolumn{4}{|c|}{ Strategi Mengulang } \\
\hline \multirow[t]{2}{*}{1} & \multirow{2}{*}{ Mengulang } & $\begin{array}{l}\text { Mengulang-ngulang } \\
\text { materi yang dipelajari }\end{array}$ & 9 siswa & $\begin{array}{c}32,1 \\
\%\end{array}$ \\
\hline & & $\begin{array}{l}\text { Membuat jadwal } \\
\text { belajar di rumah }\end{array}$ & $\begin{array}{c}15 \\
\text { siswa }\end{array}$ & $\begin{array}{c}53,5 \\
\%\end{array}$ \\
\hline \multirow[t]{2}{*}{2} & \multirow[b]{2}{*}{$\begin{array}{l}\text { Menggaris } \\
\text { Bawah }\end{array}$} & $\begin{array}{l}\text { Menyalin materi yang } \\
\text { penting }\end{array}$ & $\begin{array}{c}13 \\
\text { siswa }\end{array}$ & $\begin{array}{c}46,4 \\
\%\end{array}$ \\
\hline & & $\begin{array}{l}\text { Menggarisbawahi kata } \\
\text { kunci / kata penting } \\
\text { dalam suatu teks atau } \\
\text { materi }\end{array}$ & $\begin{array}{c}16 \\
\text { siswa }\end{array}$ & $\begin{array}{c}57,1 \\
\%\end{array}$ \\
\hline 3 & $\begin{array}{l}\text { Membuat } \\
\text { catatan } \\
\text { pinggir }\end{array}$ & $\begin{array}{l}\text { Melingkari kata-kata } \\
\text { yang tidak dimengerti }\end{array}$ & 2 siswa & $7,1 \%$ \\
\hline No & Kategori & Pernyataan & $\begin{array}{l}\text { Jumlah } \\
\text { Siswa }\end{array}$ & $\begin{array}{l}\text { Perse } \\
\text { ntase }\end{array}$ \\
\hline B & \multicolumn{4}{|c|}{ Strategi Elaborasi } \\
\hline 1 & $\begin{array}{l}\text { Pembuatan } \\
\text { Catatan }\end{array}$ & $\begin{array}{l}\text { Membuat catatan saat } \\
\text { belajar }\end{array}$ & $\begin{array}{c}10 \\
\text { siswa }\end{array}$ & $\begin{array}{c}35,7 \\
\%\end{array}$ \\
\hline 2 & Analogi & $\begin{array}{l}\text { Membandingkan dua } \\
\text { benda dengan cirri-ciri } \\
\text { yang sama }\end{array}$ & $\begin{array}{c}11 \\
\text { siswa }\end{array}$ & $\begin{array}{c}39,2 \\
\%\end{array}$ \\
\hline 3 & $\begin{array}{l}\text { Membaca } \\
\text { Selintas } \\
\text { Dengan } \\
\text { Cepat } \\
\end{array}$ & $\begin{array}{l}\text { Membaca selintas } \\
\text { dengan cepat }\end{array}$ & 7 siswa & $25 \%$ \\
\hline 4 & Bertanya & $\begin{array}{l}\text { Bertanya kepada orang } \\
\text { tua, kakak atau guru } \\
\text { tentang materi yang }\end{array}$ & $\begin{array}{c}17 \\
\text { siswa }\end{array}$ & $\begin{array}{c}60,7 \\
\%\end{array}$ \\
\hline
\end{tabular}


JURNAL KIPRAH, Desember 2018; V1(2): 25-31

e-ISSN: 2580-6947

p-ISSN: 2354-7278

\begin{tabular}{|c|c|c|c|c|}
\hline & & sulit & & \\
\hline 5 & Membaca & $\begin{array}{l}\text { Membaca seluruh } \\
\text { materi yang ada }\end{array}$ & 9 siswa & $\begin{array}{c}32,1 \\
\%\end{array}$ \\
\hline 6 & Refleksi & $\begin{array}{l}\text { Mengulas atau } \\
\text { menyulah materi yang } \\
\text { telah dipelajari dengan } \\
\text { materi baru }\end{array}$ & 3 siswa & $\begin{array}{c}10,7 \\
\%\end{array}$ \\
\hline 7 & $\begin{array}{l}\text { Tanya } \\
\text { Jawab } \\
\text { Sendiri }\end{array}$ & $\begin{array}{l}\text { Tanya jawab sendiri di } \\
\text { rumah }\end{array}$ & 2 siswa & $7,1 \%$ \\
\hline 8 & $\begin{array}{l}\text { Mengulang } \\
\text { Secara } \\
\text { Menyeluru } \\
\text { h }\end{array}$ & $\begin{array}{l}\text { Mengulang secara } \\
\text { menyeluruh materi } \\
\text { yang telah dipelajari }\end{array}$ & $\begin{array}{c}13 \\
\text { siswa }\end{array}$ & $\begin{array}{c}46,4 \\
\%\end{array}$ \\
\hline 9 & $\begin{array}{l}\text { Pembuatan } \\
\text { Ringkasan }\end{array}$ & $\begin{array}{l}\text { Meringkas suatu } \\
\text { materi }\end{array}$ & $\begin{array}{c}11 \\
\text { siswa }\end{array}$ & $\begin{array}{c}39,2 \\
\%\end{array}$ \\
\hline $\mathbf{C}$ & \multicolumn{4}{|c|}{ Strategi Organisasi } \\
\hline 1 & $\begin{array}{l}\text { Kerangka } \\
\text { garis besar }\end{array}$ & $\begin{array}{l}\text { Membuat kerangka } \\
\text { garis-garis besar dari } \\
\text { materi yang telah } \\
\text { dipelajari atau } \\
\text { mencatat kata kunci } \\
\text { pada materi tersebut }\end{array}$ & 5 siswa & $\begin{array}{c}17,8 \\
\%\end{array}$ \\
\hline 2 & $\begin{array}{l}\text { Pemetaan } \\
\text { konsep }\end{array}$ & $\begin{array}{l}\text { Mengaitkan } \\
\text { pengetahuan yang } \\
\text { telah dimiliki dengan } \\
\text { pengetahuan baru }\end{array}$ & $\begin{array}{c}10 \\
\text { siswa }\end{array}$ & $\begin{array}{c}35,7 \\
\%\end{array}$ \\
\hline 3 & Mnemonics & $\begin{array}{l}\text { Menata materi-materi } \\
\text { yang telah dipelajari, } \\
\text { agar mudah di cari dan } \\
\text { dipelajari kembali di } \\
\text { lain waktu dalam } \\
\text { jangka panjang }\end{array}$ & $\begin{array}{c}13 \\
\text { siswa }\end{array}$ & $\begin{array}{c}46,4 \\
\%\end{array}$ \\
\hline 4 & Potongan & $\begin{array}{l}\text { Memotong suatu } \\
\text { kalimat menjadi } \\
\text { beberapa potong agar } \\
\text { mudah di ingat, seperti } \\
\text { memotong nomor HP } \\
\text { menjadi beberapa } \\
\text { potong agar mudah di } \\
\text { ingat }\end{array}$ & 6 siswa & $\begin{array}{c}21,4 \\
\%\end{array}$ \\
\hline 5 & Singkatan & $\begin{array}{l}\text { Membuat singkatan } \\
\text { pada suatu kata atau } \\
\text { kalimat seperti DPR } \\
\text { singkatan dari Dewan } \\
\text { Perwakilan Rakyat }\end{array}$ & $\begin{array}{c}11 \\
\text { siswa }\end{array}$ & $\begin{array}{c}39,2 \\
\%\end{array}$ \\
\hline D & \multicolumn{4}{|c|}{ Strategi Metakognitif } \\
\hline 1 & $\begin{array}{l}\text { Kemampua } \\
\text { n Siswa }\end{array}$ & $\begin{array}{l}\text { Mempraktikan atau } \\
\text { melakukan percobaan }\end{array}$ & 8 siswa & $\begin{array}{c}28,5 \\
\%\end{array}$ \\
\hline
\end{tabular}

menunjukan bahwa:

1. Strategi Mengulang

Pada strategi mengulang terdapat 9 siswa selalu mengulang-ngulang materi yang dipelajari dengan persentase $32,1 \%$ dan terdapat 15 siswa yang selalu membuat jadwal belajar dirumah dengan persentase $53,5 \%$. Pada indikator menggarisbawahi terdapat 13 siswa yang selalu menyalin materi yang penting dengan persentase $46,4 \%$ dan terdapat 16

siswa yang selalu menggarisbawahi kata kunci / kata penting dalam suatu teks atau materi dengan persentase $57,1 \%$.

Strategi mengulang merupakan strategi belajar yang terdiri atas beberapa indikator yaitu mengulang, menggarisbawahi dan membuat catatan pinggir. Berdasarkan pendapat Nur dalam Trianto (2013: 13) strategi mengulang membantu memindahkan pembelajaran dari jangka pendek ke jangka panjang. Strategi mengulang pelajaran indikator mengulang banyak dilakukan oleh siswa setelah pulang sekolah agar mereka tidak lupa. Hal ini sesuai dengan hasil wawancara dengan beberapa siswa yang mengatakan bahwa "saya mengulang materi yang telah dibaca agar ingat kembali". Apa yang disampaikan oleh siswa sejalan dengan pendapat Mohammad dalam Fathurrohman (2016: 56) yang menyatakan bahwa dengan belajar terus-menerus dan diulangulang maka akan mempermudah siswa dalam memahami materi yang dipelajarinya dan memudahkan ingatan siswa.

2. Strategi Elaborasi

Pada hasil angket tabel 1 menunjukan pada strategi elaborasi diketahuai pada indikator membuat catatan pinggir terdapat 2 siswa yang selalu melingkari kata-kata yang tidak dimengerti dengan persentase $7,1 \%$. Strategi elaborasi indikator pembuatan catatan terdapat 10 siswa yang selalu membuat catatan saat belajar dengan persentase $35,7 \%$, pada indikator analogi terdapat 11 siswa yang selalu membandingkan dua benda dengan ciriciri yang sama dengan persentase $39,2 \%$, pada indikator membaca selintas dengan cepat terdapat 7 siswa yang selalu membaca selintas dengan cepat dengan persentase $25 \%$, pada indikator bertanya terdapat 17 siswa yang selalu bertanya kepada orang tua, kakak atau guru tentang materi yang sulit dengan persentase $60,7 \%$. 
Pada indikator membaca terdapat 9 siswa yang selalu membaca seluruh materi yang ada dengan persentase $32,1 \%$, pada indikator refleksi terdapat 3 siswa yang selalu mengulas atau menyulah materi yang telah dipelajari dengan materi baru dengan persentase $10,7 \%$, pada indikator tanya jawab sendiri terdapat 2 siswa yang selalu tanya jawab sendiri dirumah dengan persentase $7,1 \%$, pada indikator mengulang secara menyeluruh terdapat 13 siswa yang selalu mengulang secara menyeluruh materi yang telah dipelajari dengan persentase $46,4 \%$, pada indikator pembuatan ringkasan terdapat 11 siswa yang selalu meringkas suatu materi dengan persentase $39,2 \%$.

Strategi elaborasi merupakan strategi belajar yang terdiri atas beberapa indikator yaitu pembuatan catatan, analogi, membaca selintas dengan cepat, bertanya, membaca, refleksi, tanya jawab sendiri, mengulang secara menyeluruh, dan pembuatan ringkasan. Berdasarkan pendapat Nur dalam Trianto (2013: 13) strategi elaborasi merupakan proses penambahan rincian sehingga informasi baru akan lebih bermakna, dengan membuat pengkodean dapat lebih mempermudah dan lebih memberikan kepastian. Strategi elaborasi membantu memindahkan informasi dari jangka pendek ke jangka panjang dengan menggabungkan informasi baru dengan apa yang telah diketahui siswa.

3. Strategi Organisasi

Strategi organisasi pada indikator kerangka garis besar terdapat 5 siswa yang selalu membuat kerangka garis-garis besar dari materi yang telah dipelajari atau mencatat kata kunci pada materi tersebut dengan persentase $17,8 \%$, pada indikator pemetaan konsep terdapat 10 siswa yang selalu mengaitkan pengetahuan yang telah dimiliki dengan pengetahuan baru dengan persentase $35,7 \%$.

Pada indikator Mnemonics terdapat 13 siswa yang selalu menata materi-materi yang telah dipelajari, agar mudah dicari dan dipelajari kembali di lain waktu dalam jangka panjang dengan persentase $46,4 \%$, pada indikator potongan terdapat 6 siswa yang selalu memotong suatu kalimat menjadi beberapa potong agar mudah diingat dengan persentase $21,4 \%$, pada indikator singkatan terdapat 11 siswa yang selalu membuat singkatan pada suatu kata atau kalimat seperti DPR singkatan dari Dewan Perwakilan Rakyat dengan persentase $39,2 \%$.

Strategi organisasi merupakan strategi belajar yang terdiri atas beberapa indikator yaitu kerangka garis besar, pemetaan konsep, mnemonics potongan, dan singkatan. Berdasarkan pendapat Nur dalam Trianto (2013: 13) strategi Organisasi ini membantu siswa meningkatkan kebermaknaan bahan-bahan baru, terutama dilakukan dengan menggunakan struktur - struktur pengorganisasian baru pada bahan-bahan tersebut.

4. Strategi Metakognitif

Strategi metakognitif pada indikator kemampuan siswa terdapat 8 siswa yang selalu mempraktikan atau melakukan percobaan dengan persentase $28,5 \%$. Strategi metakognitif ini biasa siswa lakukan di sekolah maupun di rumah sesuai dengan berpikir mereka sendiri. Hasil wawancara dengan siswa yang menyatakan bahwa belajar dengan mempraktikan atau melakukan percobaan itu penting karena lebih mudah dan lebih cepat memahaminya. Apa yang disampaikan oleh siswa sejalan dengan pendapat Riyadi (2012: 33) yang berpendapat bahwa siswa yang menggunakan strategi metakognitif cenderung akan lebih mudah dalam belajarnya dan akan lebih mudah dalam memecahkan masalah dan lebih mudah dalam mengingat materi yang telah dipelajarinya. 
Dari hasil tersebut dapat diketahui bahwa hasil persentase strategi belajar mandiri siswa kelas VI yang didapat dari data kuantitatif menunjukan bahwa sebagian besar siswa menggunakan strategi bertanya yang masuk dalam kategori strategi belajar elaborasi, terdapat 17 siswa yang selalu bertanya kepada orang tua, kakak atau guru tentang materi yang sulit dengan persentase $60,7 \%$. Kedua yaitu menggaris bawahi yang masuk dalam kategori strategi belajar mengulang, terdapat 16 siswa yang selalu menggarisbawahi kata kunci/kata penting dalam suatu teks atau materi dengan persentase $57,1 \%$. Ketiga yaitu mengulang yang masuk dalam kategori mengulang, terdapat 15 siswa yang mengulang materi dan membuat jadwal saat belajar dengan persentase 53,5\% dan berdasarkan 10 siswa yang peneliti wawancara secara keseluruhan siswa menggunakan strategi belajar yang ada, akan tetapi sebagian besar siswa lebih cenderung menggunakan strategi bertanya ketika mendapatkan materi yang sulit yang masuk dalam kategori strategi belajar elaborasi. Selain itu siswa juga banyak belajar dengan menggarisbawahi dan mengulang-ulang materi yang telah dipelajari yang masuk dalam kategori strategi belajar menggulang. Jadi dapat diketahui bahawa data kualitatif yang diperoleh dengan wawancara membuktikan dan menguatkan data kuantitatif yang didapat melalui angket.

Slameto (2013: 76) menjelaskan bahwa belajar yang efesien dapat tercapai apabila dapat menggunakan strategi belajar yang tepat. Berdasarkan pendapat Michael Pressley dalam Trianto (2013: 139) strategi belajar yaitu operator-operator kognitif meliputi dan terdiri atas proses-proses yang secara langsung terlibat dalam menyelesaikan suatu tugas (belajar). Strategi-strategi tersebut merupakan strategistrategi yang digunakan siswa untuk memecahkan masalah belajar tertentu. Untuk menyelesaikan tugas belajar siswa memerlukan keterlibatan dalam proses-proses berpikir dan berprilaku, men-skim atau membaca sepintas judul-judul utama, meringkas, dan membuat catatan, di samping itu juga memonitor jalan berpikir diri sendiri. Siswa yang memiliki strategi belajar yang sangat baik maka akan memperoleh hasil belajar yang baik pula dan sebaliknya siswa yang memiliki strategi belajar yang kurang maka akan menghasilkan hasil belajar yang kurang maksimal.

Hal tersebut sesuai dengan Penelitian Fitria L. (2013: 95-101) yang berjudul "Perbedaan Persiapan Siswa yang Hasil Belajar Tinggi dan Rendah dalam Menghadapi Ujian Nasional pada Tahun 2013", menunjukan hasil bahwa dalam menghadapi UN diperlukan persiapan fisik, psikis, dan materi, siswa yang mendapatkan hasil belajar tinggi dapat mencapai di atas $70 \%$ dan siswa yang mendapatkan hasil belajar rendah di bawah $55 \%$. Strategi belajar diperlukan untuk dapat mencapai hasil yang semaksimal mungkin. Tidak heran jika siswa yang telah mengetahui strategi dalam belajarnya sendiri, maka siswa tersebut cenderung lebih cepat memahami materi yang dipelajarinya. Hal tersebut sesuai dengan pendapat Suyono \& Hariyanto (2014: 12) mengatakan bahwa siswa yang telah memahami strategi belajarnya sendiri akan lebih cepat dan mudah dalam belajarnya dan belajar dikatakan berhasil jika seseorang mampu mengulangi kembali materi yang telah dipelajarinya.

Keberhasilan belajar siswa dipengaruhi pada bagaimana siswa dalam belajar atau dapat dikatakan bahwa strategi belajar sangat menentukan keberhasilan belajar siswa. Hal tersebut sesuai dengan pendapat Slameto (2015: 54) mengatakan bahwa terdapat dua faktor yang mempengaruhi keberhasilan siswa yaitu faktor intern dan ekstern. Faktor intern meliputi faktor jasmaniah dimana siswa yang sedang sakit atau memiliki cacat tubuh dapat mempengaruhi keberhasilan belajar berbeda dengan siswa yang sehat yang dapat berpikir secara maksimal, bersemangat dan tidak mudah lelah, kemudian faktor psikologi dimana siswa yang selalu perhatian, memiliki minat belajar yang tinggi, memiliki bakat, memiliki kematangan dan selalu siap dalam belajar maka 
akan mendapatkan hasil belajar yang baik berbeda dengan siswa yang selalu bermalasmalasan, dan faktor kelelahan dimana siswa yang terlihat lelah dalam belajar tentu tidak akan bisa berkonsentrasi dan tidak bersemangat yang menyebabkan hasil belajar yang kurang, untuk itu siswa jangan sampai kelelahan dalam belajar.

Faktor ekstern meliputi faktor keluarga yaitu bagaimana cara orang tua dalam mendidik siswa, keadaan rumah dan kondisi ekonomi akan mempengaruhi hasil belajar siswa, dimana orang tua yang mendidik anak untuk selalu belajar, keadaan rumah yang tenang dan kondisi ekonomi yang terpenuhi untuk memberikan makan yang bergizi maka akan menghasilkan hasil belajar siswa yang baik, berbeda dengan siswa yang tidak diperhatikan oleh orang tuanya saat belajar, rumah yang ramai/gaduh akan mengakibatkan belajar siswa menjadi kacau, kemudian faktor sekolah dimana guru yang bisa menggunakan metode mengajar dengan baik, kurikulum yang digunakan sesuai, alat pelajaran yang mendukung akan menghasilkan hasil belajar yang maksimal, dan faktor masyarakat dimana siswa yang berada di lingkungan yang baik dan tenang akan dapat lebih berkonsentrasi dalam belajarnya sehingga menghasilkan hasil belajar yang baik, berbeda dengan siswa yang berada di lingkungan yang ramai seperti dekat pasar. Keberhasilan belajar siswa banyak dipengaruhi oleh faktor kesehatan siswa, faktor keluarga yaitu bagaimana orang tua dalam mendidik, mengawasi dan mengarahkan dalam belajarnya, selain itu dipengaruhi juga oleh faktor sekolah yaitu bagaimana metode mengajar dan metode belajar yang diajarkan oleh guru.

\section{Kesimpulan}

Berdasarkan hasil penelitian dan analisis data, maka dapat disimpulkan bahwa sebagian besar siswa menggunakan strategi bertanya yang masuk dalam kategori strategi belajar elaborasi dengan persentase $60,7 \%$. Kedua yaitu menggarisbawahi yang masuk dalam kategori strategi belajar mengulang dengan persentase $57,1 \%$. Ketiga yaitu mengulang yang masuk dalam kategori mengulang dengan persentase 53,5\%, akan tetapi secara keseluruhan siswa menggunakan semua strategi belajar yang ada. Keberhasilan belajar siswa sangat dipengaruhi oleh faktor intern dan faktor ekstern terutama faktor kesehatan, faktor keluarga dan faktor sekolah.

\section{DAFTAR PUSTAKA}

Arifin, Z. (2012). Penelitian Pendidikan. Bandung: PT Remaja Rosdakarya.

Fatkhurrokhman, M. (2016). Strategi Belajar Siswa Pada Kegiatan Praktik Kerja Industri Dalam Memperoleh Kompetensi. Jurnal Ilmiah Pendidikan Teknik Elektro. 1, (1), 47-58

Fitria, L. (2013). Perbedaan Persiapan Siswa yang Hasil Belajar Tinggi dan Rendah dalam Menghadapi Ujian. Jurnal Konseling dan Pendidikan. 1, (2), 95101.

POS USBN tahun pelajaran 2017/ 2018.

Purwanto, N. (2014). Psikologi Pendidikan. Bandung: PT Remaja Rosdakarya.

Riyadi, I. (2012). Strategi Belajar Meta Kognisi untuk meningkatkan kompetensi siswa pada mata pelajaran IPS. Jurnal Magistra: 28-36.

Slameto. (2015). Belajar dan Faktor-faktor yang Mempengaruhinya. Jakarta: Rineka Cipta.

Suyono \& Hariyanto. (2014). Belajar dan Pembelajaran. Bandung: PT Remaja Rosdakarya.

Trianto. (2013). Mendesain Model Pembelajaran Inovatif-Progresif. Jakarta: Kencana. 